\title{
Study of the Role of Serum Procalcitonin Level in Differentiation between Bacterial and Viral meningitis
}

\author{
Mohamed A. Nouh ${ }^{1}$, Gamal S. Eldeeb ${ }^{1}$, Mohamed S. Rizk ${ }^{2}$, \\ Mohamed S. Abdelhakam ${ }^{3}$ \\ ${ }^{1}$ Tropical Medicine Department, Faculty of Medicine, Menoufia University, Egypt \\ ${ }^{2}$ Biochemistry Department, Faculty of Medicine - Menoufia University, Egypt. \\ ${ }^{3}$ Menouf Fever Hospital, Egypt
}

Corresponding Author Mohamed Salama Abdelhakam

Mobile:

$+201061814831$

E mail:

mohammed.salama.ab del.hakam@Gmail .com

Key words: Serum PCT. Septic meningitis .Aseptic meningitis
Background and Study aim: Serum procalcitonin (PCT) is specific for the diagnosis of bacterial infection. The aim of this study is to evaluate the role of serum PCT in diagnosis of septic meningitis in adults and its efficacy in differential diagnosis.

Patients and Methods: The study included 30 adults of septic meningitis and 30 adults with aseptic meningitis admitted in Menouf Fever Hospital and Tropical Medicine Department with fever, headache, vomiting and seizure. The diagnosis of septic meningitis was based on clinical features; physical examination, blood and cerebrospinal fluid (CSF) cytochemical findings, Gram stain and bacterial culture. Thirty cases of aseptic meningitis admitted during same period were also included in the study, and 20 subjects of matched age and sex, free from any CNS diseases

\section{INTRODUCTION}

Despite the advances in diagnosis and treatment of infectious diseases, meningitis and encephalitis are still considered as important causes of mortality and morbidity [1]. To reduce the morbidity and mortality related to bacterial meningitis, it is important to discriminate bacterial meningitis from aseptic meningitis during the acute phase of the disease, when the clinical symptoms are often similar [2]. An ideal marker for bacterial infections should allow early diagnosis, inform about the course and prognosis of the disease, and facilitate therapy [3]. Clinical criteria, Gram staining, and bacterial antigen testing of CSF as well as the classic biological markers in the blood (C-reactive protein [CRP] undergoing spinal anaesthesia for non CNS surgical causes as control. Serum PCT was measured by Gloryscience ELISA Kit.

Results: Serum PCT level was significantly higher in patients with septic meningitis than those with aseptic meningitis $(\mathrm{P}<0.001)$. In culture and Gram stain positive 23 and 20 cases respectively, serum PCT was significantly elevated (23.123 \pm $9.894 \mathrm{pg})$ than aseptic meningitis $(8.652 \pm$ $1.777 \mathrm{pg})(\mathrm{P}<0.001)$. At optimum cut off value of $\geq 10.36 \mathrm{pg} / \mathrm{mL}$, based on area under receiver operating characteristic (ROC) curve, PCT showed sensitivity, specificity of $100 \%$ and $86.6 \%$ respectively for the differentiation of septic from aseptic meningitis.

Conclusions: Serum PCT may be used as diagnostic marker for septic meningitis and its differentiation from aseptic meningitis.

level, white blood cell count [WBC], and neutrophil count) or CSF (protein level, glucose level, WBC count, and neutrophil count) used alone do not offer $100 \%$ sensitivity with high specificity for distinguishing between bacterial and aseptic meningitis [3]. Waiting for at least 2 days was recommended to identify bacterial growth in CSF cultures, whereas this period is 3-8 days for viral cultures [4]. Moreover, identifying the frequently encountered viral agents via polymerase chain reaction is not always possible in every institution. Therefore, intensive research has been carried out to find new and rapid diagnostic methods for differential diagnosis of bacterial and viral meningitis [5]. PCT, which is a calcitonin 
propeptide, is supposed to be synthesized in $\mathrm{C}$ cells of the thyroid gland and secreted from leukocytes of the peripheral blood [6]. Serum PCT is more specific for the diagnosis of bacterial infection [7]. PCT levels do not or only slightly increase in non-bacterial inflammatory syndromes. PCT also provides prognostic information and risk stratification assessment in the emergency unit [8]. It was previously shown that serum PCT levels increase during the course of bacterial, parasitic, or fungal infections, but remain normal or slightly increase in viral infections and inflammatory reactions that are not infectious [9].

\section{PATIENTS AND METHODS}

For this purpose, adult patients with clinical presentations of meningitis (41 males and 19 females) were included in the study who presented to Menouf Fever Hospital in the period between April 2014 and March 2015. These patients were classified according to the results of CSF findings into 30 patients of septic meningitis as group I (GI) and 30 patients of aseptic meningitis as group II (GII). In addition to 20 subjects of matched age and sex, free from any CNS diseases undergoing spinal anaesthesia for non CNS surgical causes were included in the study as GIII (control group).

Clinical manifestations; laboratory examination of CSF (glucose, protein, leukocyte count, Gram stain and bacterial cultures); and serum inflammatory markers (peripheral blood leukocyte count and CRP) were evaluated for their ability to differentiate bacterial from aseptic meningitis.

All patients and control were examined using Gloryscience PCT kits for serum PCT level.

\section{Statistical analysis:}

Statistical presentation and analysis of the present study was conducted, using the mean, standard deviation, student t-test, Paired t-test, Chi-square and Mann-Whitney by SPSS V17.

The results were tabulated and statistical analysis was done and the results were considered significant at $\mathrm{P}$ value $<0.05$.

\section{Diagnostic validity test:}

a. The diagnostic sensitivity: It is the percentage of diseased cases truly diagnosed among total diseased cases or the ability of the screening test to discover the truly positive cases.

b. The diagnostic specificity: It is the percentage of non-diseased truly excluded by the test among total non-diseased cases or the ability of the screening test to discover the truly negative cases.

c. The predictive value for a positive test: It is the percentage of cases truly diagnosed among total positive cases.

d. The predictive value for a negative test: It is the percentage of cases truly negative among total negative cases.

e. The efficacy or the diagnostic accuracy of the test: It is the percentage of cases truly diseased plus truly non-diseased among total cases.

\section{RESULTS}

Clinical symptoms and signs were of little assistance in differentiating bacterial from aseptic meningitis except for meningeal irritation signs which were found to be statistically different between septic and aseptic groups.

\section{Examination of CSF revealed:}

- A statistically significant difference in aspect of CSF between bacterial meningitis group compared to the aseptic meningitis group $(\mathrm{p}<0.001)$ (Table 1).

- Significantly higher CSF leukocyte count with marked increase in the polymorphnuclear leukocyte count, CSF protein level and low CSF glucose in the bacterial meningitis group compared to the aseptic meningitis group $(\mathrm{p}<0.001)$ (Table 2).

- CSF culture was positive in 23 patients of GI $(78 \%)$ while it was negative in 7 patients of the same group (22\%) and The most common detected organisms were St. pneumoniae (Gram positive cocci) in 11 patients out of 23 positive cultures $(47.8 \%), N$. meningitidis (Gram negative diplococci) in 7 patients $(30.4 \%), H$. influenza (Gram negative pleomorphic rods) in 3 patients (13.04\%). Staph. aureus and E. coli were the least common organisms with the incidence of (4.33\%)for both (Table 3 ).

- High statistically significant differences in ESR and CRP between patients with septic meningitis and those with aseptic meningitis.

- CRP results were positive in $80 \%$ of patients with bacterial meningitis, and $20 \%$ of patients with aseptic meningitis (Table 4). 
- The mean values of peripheral blood WBCs were 13830 in GI and 8543 in GII respectively, and these results were statistically highly significant $(\mathrm{p}<0.001)$.

- High level of serum PCT in septic (23.123 \pm $9.894 \mathrm{pg} / \mathrm{dl}$ ) when compared with aseptic meningitis $(8.652 \pm 1.777 \mathrm{pg} / \mathrm{dl})$ and control group $(6.045 \pm 0.908 \mathrm{pg} / \mathrm{dl})$ (Table 5).

- Cut off PCT level >7.5 pg/dL clearly distinguished patients with meningitis from control group (all patients with bacterial and viral meningitis had a serum PCT level above this level).

- Cut off PCT level $>10.36$ pg/dL differentiate patients with bacterial meningitis from those with aseptic meningitis with $100 \%$ sensitivity and $86.6 \%$ specificity (Table 6 ).

Table (1): Physical findings of the CSF of group I in comparison to group II

\begin{tabular}{|c|c|c|c|c|c|c|c|c|c|}
\hline \multirow{2}{*}{\multicolumn{2}{|c|}{ Variable }} & \multicolumn{2}{|c|}{$\begin{array}{c}\text { Group I } \\
\mathbf{N}=\mathbf{3 0} \\
\end{array}$} & \multicolumn{2}{|c|}{$\begin{array}{c}\text { Group II } \\
\mathbf{N}=\mathbf{3 0} \\
\end{array}$} & \multicolumn{2}{|c|}{$\begin{array}{c}\text { Total } \\
\mathbf{N}=\mathbf{6 0} \\
\end{array}$} & \multirow[t]{2}{*}{$X^{2}$} & \multirow{2}{*}{ P-value } \\
\hline & & $\mathbf{N}$ & $\%$ & $\mathbf{N}$ & $\%$ & $\overline{\mathbf{N}}$ & $\%$ & & \\
\hline \multirow{3}{*}{ Colour } & Colorless & 20 & 66.67 & 24 & 80.00 & 44 & 73.33 & \multirow{3}{*}{2.010} & \multirow{3}{*}{0.366} \\
\hline & Whitish & 7 & 23.33 & 3 & 10.00 & 10 & 16.67 & & \\
\hline & Bloody & 3 & 10.00 & 3 & 10.00 & 6 & 10.00 & & \\
\hline \multirow{3}{*}{ Aspect } & Turbid & 19 & 63.33 & 5 & 16.67 & 24 & 40.00 & \multirow{3}{*}{17.076} & \multirow{3}{*}{$<0.001 *$} \\
\hline & Clear & 4 & 13.33 & 18 & 60.00 & 22 & 36.67 & & \\
\hline & Hazy & 7 & 23.33 & 7 & 23.33 & 14 & 23.33 & & \\
\hline
\end{tabular}

Table (2): Cytological and chemical findings of the CSF the studied groups

\begin{tabular}{|c|c|c|c|c|c|}
\hline \multicolumn{2}{|c|}{ Variable } & Group I & Group II & $\mathbf{t}$ & P-value \\
\hline \multirow{2}{*}{$\begin{array}{c}\text { CSF } \\
\text { glucose }\end{array}$} & Range & $10-58$ & $16-168$ & \multirow{2}{*}{-6.568} & \multirow{2}{*}{$<0.001^{*}$} \\
\hline & Mean \pm SD & $28.700 \pm 14.613$ & $74.333 \pm 35.139$ & & \\
\hline \multirow{2}{*}{$\begin{array}{c}\mathrm{CSF} \\
\text { protein }\end{array}$} & Range & $25-396$ & $12-116$ & \multirow{2}{*}{4.484} & \multirow{2}{*}{$<0.001 *$} \\
\hline & Mean \pm SD & $143.633 \pm 115.927$ & $45.000 \pm 32.768$ & & \\
\hline \multirow{2}{*}{$\begin{array}{c}\text { CSF } \\
\text { WBCs }\end{array}$} & Range & $550-45000$ & $15-315$ & \multirow{2}{*}{3.518} & \multirow{2}{*}{$0.001 *$} \\
\hline & Mean \pm SD & $6224.000 \pm 9497.920$ & $123.967 \pm 87.344$ & & \\
\hline \multirow{2}{*}{$\begin{array}{c}\text { CSF } \\
\text { neutrophils }\end{array}$} & Range & $45-90$ & $10-50$ & \multirow{2}{*}{13.700} & \multirow{2}{*}{$<0.001 *$} \\
\hline & Mean \pm SD & $69.833 \pm 11.633$ & $30.667 \pm 10.483$ & & \\
\hline
\end{tabular}

Table (3): Organisms isolated from CSF of septic meningitis patients

\begin{tabular}{|l|c|c|c|c|}
\hline \multirow{2}{*}{ Organisms } & \multicolumn{2}{c|}{ CSF culture } & \multicolumn{2}{c|}{ Gram stain } \\
\cline { 2 - 5 } & $\mathbf{N}$ & $\mathbf{\%}$ & $\mathbf{N}$ & $\mathbf{\%}$ \\
\hline St. pneumoniae & 11 & 47.8 & 10 & 50 \\
\hline Meningocci & 7 & 30.4 & 5 & 25 \\
\hline H. influenza & 3 & 13.04 & 3 & 12.5 \\
\hline Staph. aureus & 1 & 4.34 & 1 & 4.16 \\
\hline E. coli & 1 & 4.34 & 1 & 4.16 \\
\hline
\end{tabular}


Table (4): CRP of group I in comparison to group II

\begin{tabular}{|c|c|c|c|c|c|c|c|c|}
\hline \multirow{2}{*}{ CRP } & \multicolumn{2}{|c|}{ Group I } & \multicolumn{2}{|c|}{ Group II } & \multicolumn{2}{|c|}{ Total } & \multirow{2}{*}{$\mathbf{2}^{\mathbf{2}}$} & \multirow{2}{*}{ P-value } \\
\cline { 2 - 7 } & $\mathbf{N}$ & $\mathbf{\%}$ & $\mathbf{N}$ & $\mathbf{\%}$ & $\mathbf{N}$ & $\mathbf{\%}$ & \multirow{2}{*}{2} & \\
\hline Negative & 6 & 20.00 & 24 & 80.00 & 30 & 50.00 & \\
\hline Positive & 24 & 80.00 & 6 & 20.00 & 30 & 50.00 & \multirow{2}{*}{21.600} & $<0.001^{*}$ \\
\hline Total & 30 & 100.00 & 30 & 100.00 & 60 & 100.00 & & \\
\hline
\end{tabular}

Table (5): Values of mean \& SD of serum PCT among the three studied groups

\begin{tabular}{|c|c|c|c|c|}
\hline \multirow{2}{*}{ Groups } & Range & \multirow{2}{*}{ PCT } & \multirow{2}{*}{ P-value } \\
\cline { 2 - 3 } & $10.5-42.8$ & $23.123 \pm 9.894$ & & \\
\hline Group I & $5.8-11.88$ & $8.652 \pm 1.777$ & 60.041 & $<0.001^{*}$ \\
\hline Group II & $5.2-8.4$ & $6.045 \pm 0.908$ & & \\
\hline Group III & \multicolumn{2}{|c|}{ TUKEY'S Test } & II\&III \\
\hline \multicolumn{2}{|c|}{ I\&III } & \multicolumn{2}{c|}{0.316} \\
\hline I\&II & \multicolumn{2}{|c|}{$<001^{*}$} &
\end{tabular}

Table (6): Accuracy of serum PCT level in differentiation between bacterial meningitis and aseptic meningitis

\begin{tabular}{|c|c|c|c|c|c|}
\hline \multicolumn{5}{|c|}{ PCT ROC curve } \\
\hline Cutoff & Sens. & Spec. & PPV & NPV & Accuracy \\
\hline$>10.36^{*}$ & $100.0 \%$ & $86.6 \%$ & $88.2 \%$ & $100.0 \%$ & $98.2 \%$ \\
\hline
\end{tabular}

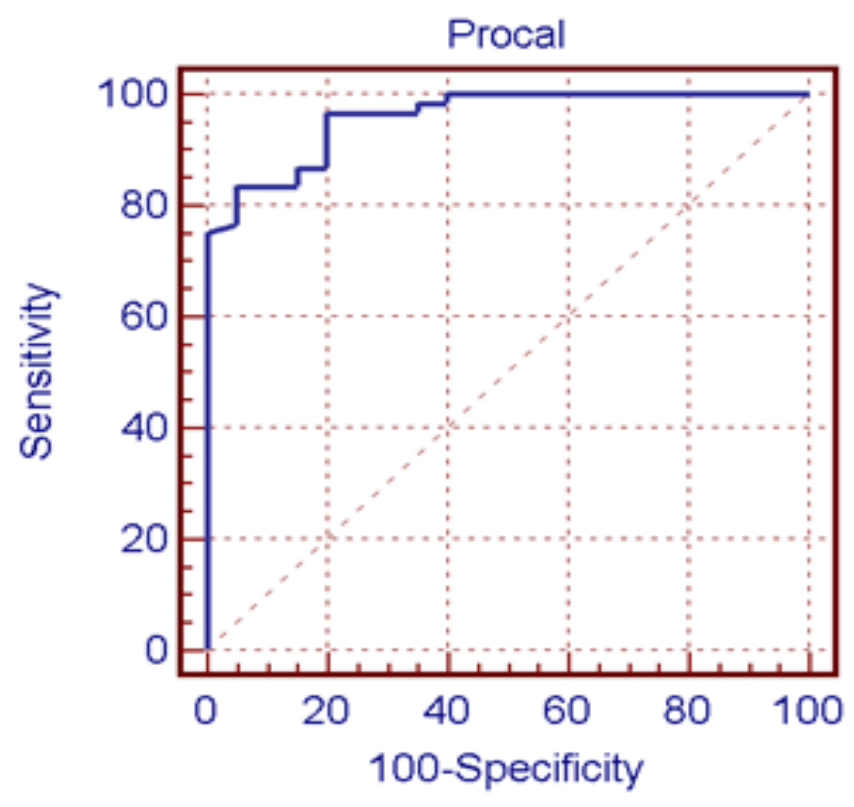

Figure (1): ROC curve for sensitivity and specificity of serum PCT level in diagnosis of meningitis. 


\section{DISCUSSION}

In the present study, serum PCT level was found significantly higher in the septic meningitis group than the control group. Further in septic meningitis group, higher level was found than aseptic meningitis group. The diagnostic value of serum PCT was calculated with optimum combination of sensitivity and specificity at optimum cut off level obtained through receiver operating characteristic curve (ROC).

These results agree with Prasad et al. [10] who reported that the mean level of serum PCT in patients with septic meningitis and control group was $(22,669.21 \pm 7,656.45 \mathrm{pg} / \mathrm{ml})$ and $(3,943.8 \pm$ $632.27 \mathrm{pg} / \mathrm{ml}$ ) respectively and showed a highly significant difference among both groups $(\mathrm{p}<0.001)[10]$.

Kepa et al. [11] in another study carried out on17 adult patients with suppurative bacterial meningoencephalitis and 16 patients with lymphocytic meningitis measured the levels of serum and CSF PCT and concluded that using serum PCT is a key element in differentiating bacterial meningitis from viral meningitis.

These results also agree with Knudsen et al. [12] who concluded that PCT and CRP had very high diagnostic accuracy for distinguishing between bacterial and non bacterial infection in patients with spinal fluid pleocytosis.

Ray et al. [13] in a prospective study carried out on 151 adult patients with meningitis signs concluded that laboratory test results of cerebrospinal fluid are of moderate importance in differentiating bacterial meningitis from the nonbacterial meningitis in cases which Gram staining for bacteria is negative in the beginning however serum PCT is an excellent predictive factor for differentiating acute bacterial meningitis which is similar to our study.

Dubos et al. [14] found that a PCT used alone offered the best sensitivity (99\%) and specificity $(83 \%)$ in agreement with our results.

In this study, the level of PCT was significantly higher among patients with neck rigidity.

Andreola et al. [15] agreed that CRP and PCT are both valuable markers for detection of severe bacterial infection in children according to the serum PCT characteristics which agree with the results of the present study.
The present study revealed highly significant increase in ESR $\left(1^{\text {st }} \mathrm{h}\right)$ and CRP in GI patients when compared to GII ( $p<0.001)$.

These results were in agreement with Yetkin et al. [16] who stated that, there were high statistically significant differences in ESR $(p<0.007)$ and CRP $(p<0.001)$ between patients with septic meningitis and those with aseptic meningitis. In contrast to Makoo et al. [17] who found that ,there was no significant difference between patients with septic meningitis and those with a septic meningitis ESR $(p=0.07)$ and CRP $(p=0.35)$. This disagreement may explained by the fact that, the peripheral white blood cells, ESR and CRP can be different very early in the disease and in patients insufficiently treated by antibiotics.

In this study, CSF culture was positive in 23 patients of GI $(78 \%)$ while it was negative in 7 patients of the same group (22\%). Patients with negative culture diagnosed as septic meningitis by CSF parameters (WBCs, glucose level, protein level, aspect of CSF and Gram staining) and other inflammatory markers like CRP, peripheral TLC and ESR.

\section{CONCLUSION}

Serum PCT may be used as diagnostic marker for septic meningitis and its differentiation from aseptic meningitis. PCT may be used as prognostic marker as all cases that had bad outcome, had higher level of PCT than cured cases.

Funding: None.

Conflicts of interest: The authors declare that there is no conflict of interest.

Ethical approval: Was granted by the Institutional Review Board and informed consent was obtained from each patient prior to inclusion in the study

\section{REFERENCES}

1. Alkholi UM, Abd Al-Monem N, Abd El-Azim AA \& Sultan MH. Serum procalcitonin in viral and bacterial meningitis. J Glob Infect Dis. 2011, 3: $14-18$.

2. Abdelkader NA, Mahmoud WA, Saber SM. Serum procalcitonin in Egyptian patients with acute meningitis and a negative direct cerebrospinal fluid examination.J Infect Public Health 2014;7(2):106-13. 
3. Tian G, Pan SY, Ma G, Liao W, Su QG, Gu BC, et al. Serum levels of procalcitonin as a biomarker for differentiating between sepsis and systemic inflammatory response syndrome in the neurological intensive care unit. J Clin Neurosci. $2014 ; 21(7): 1153-8$.

4. Fielding-Singh V, Hong DK, Harris SJ, Hamilton JR, Schroeder AR. Ruling out bacteremia and bacterial meningitis in infants less than one month of age: is 48 hours of hospitalization necessary?.Hosp Pediatr 2013; 3(4):355-61.

5. Papdakis G, Chibo D, Druce J, Catton M, Birch C. Detection and genotyping of enteroviruses in cerebrospinal fluid in patients in Victoria, Australia, 2007-2013.J Med Virol. 2014 ;86(9):1609-13.

6. De Kruif MD, Limper M, Gerritsen H, Spek CA, Brandjes DP, ten Cate $\mathrm{H}$, et al. Additional value of procalcitonin for diagnosis of infection in patients with fever at the emergency department. Crit Care Med, 2010; 38(2):457-63.

7. Rustici MC, Chiappini E, Salvadori M, Sollai S, Galli L, de Martino M. Clinical usefulness of the semiquantitative procalcitonin test in the diagnosis of bacterial infections in a third level children's hospital. Clin Lab, 2011, 57: 497-506.

8. Hausfaster P. Biomarkers and infection in the emergency unit. Med Mal Infect. 2014;(14)14-6.

9. Lautaret S, Gennai S, Sellier E, Wintenberger C, François P, Carpentier F, et al.,. Suspicion of meningitis: evaluation of the management in the emergency unit. Presse Med ; 2013, 42(3):e6977.

10. Prasad R, Kapoor R, Mishra OP, Srivastava R, Kant Singh U. Serum Procalcitonin in Septic Meningitis. Indian J Pediatr 2013, 80(5):365370 .

11. Kepa, L, G.B. Oczko, D. Bledowski. Procalitonin (PCT) concentration in cerebrospinal fluid and plasma of patients with purulent and lymphocytic meningoencephalitis. Przegl Epidemiol, 2005, 59: 703-709.
12. Knudsen TB, Larsen K, Kristiansen TB, Møller HJ, Tvede M, Eugen-Olsen J, et al. Diagnostic value of soluble CD163 serum levels in patients suspected of meningitis: comparison with CRP and procalcitonin. Scand J Infect Dis ; 2007, 39: 542-53.

13. Ray P, Badarou-Acossi G, Viallon A, Boutoille D, Arthaud M, Trystram D, et al. Accuracy of the cerebrospinal fluid results to differentiate bacterial from non-bacterial meningitis, in case of negative gram-stained smear. Am $J$ Emerg Med.2007, 25: 179-184.

14. Dubos F, Korczowski B, Aygun DA, Martinot A, Prat C, Galetto-Lacour A, et al. Serum procalcitonin level and other biological markers to distinguish between bacterial and aseptic meningitis in children: a European multicenter case cohort study.Arch Pediatr Adolesc Med. 2008, 162: 1157-1163.

15. Andreola B, Bressan S, Callegaro S, Liverani A, Plebani M, Da Dalt L. Procalcitonin and Creactive protein as diagnostic markers of severe bacterial infections in febrile infants and children in the emergency department. Pediatr Infect Dis $J ;$ 2007, 26: 672-7.

16. Yetkin F, Kayabas U, Ersoy Y, Bayindir Y, Toplu SA, Tek I. Cerebrospinal Fluid Viscosity: A Novel Diagnostic Measure for Acute Meningitis. Southern Medical Journal; 2010, 103(9):892895.

17. Makoo BZ, Soltani RZ, Hasani A, Makoo BR, Mashrabi O. Diagnostic Value of Serum and Cerebrospinal Fluid Procalcitonin in Differentiation Bacterial Meningitis from Aseptic Meningitis. American Journal of Infectious Diseases 2010, 6 (4): 93-97.

Peer reviewers: Dr. Ayman Abd ElSabour Abd El-Azim, MBBCh, MSc, MD, $\mathrm{MRCPCH}$, Lecturer of Pediatrics, Zagazig University, Associate Consultant of Pediatrics, International Medical Center, Jeddah, KSA; Dr. Ghada Abd El-Ghaffar Salem, Assistant Professor, Tropical Medicine Gastroentrology and Hepatology, Faculty of Medicine, Zagazig University, Egypt. Editor: Mohamed H Emara; Lecturer of Tropical Medicine, Faculty of Medicine, Zagazig University, Egypt. 